\title{
Sınıf Öğretmenlerinin ve Sınıf Öğretmeni Adaylarının Müzik Öğretimine İlişkin Duyuşsal Özelliklerinin İncelenmesi ${ }^{1}$
}

\author{
DOI: 10.26466/opus. 890948
}

*

\author{
Hasan Açılmış ${ }^{*}$ - Bilge Kuşdemir Kayıran ** \\ * Dr. Öğr. Üyesi, Gaziantep Üniversitesi/Türk Musikisi Devlet Konservatuvarı, Gaziantep/Türkiye \\ E-Posta: acilmishasan@gmail.com \\ ORCID: $\quad \underline{0000-0003-4687-7070}$ \\ ** Doç. Dr., Gaziantep Üniversitesi /Eğitim Fakültesi, Gaziantep/Türkiye \\ Öz \\ E-Posta: kbilge01@gmail.com \\ ORCID: $\quad \underline{0000-0001-6664-2688}$
}

\begin{abstract}
Araştırmanın amacı, sını fögretmeni adayları ve sinıf öğretmenlerinin müzik öğretimine ilişkin öz yeterlik, tutum ve müziğe yönelik ilgi düzeylerini çeşitli değişkenlere göre incelemek ve bunlar arasında bir ilişki olup olmadığını, varsa bu ilişkinin ne yönde ve hangi düzeyde olduğunu belirlemektir. Araştırmanın örneklemini Gaziantep ve Adana illerinde çalışan/öğrenim gören sinı öğretmeni adayları ve sinı öğretmenleri oluşturmaktadır. Veri toplama aracı olarak, "Müzik Öğretimi Öz Yeterlik Ölçeği", "Müziğe Yönelik İlgi Ölçeği" ve "Müzik Öğretimine İlişkin Tutum Ölçeği" kullanılmıştır. Elde edilen veriler, betimsel analiz, bağımsız gruplar t-testi, tek yönlü varyans ve korelasyon analizi yöntemleri kullanılarak analiz edilmiştir. Araştırma sonucunda, sınıf öğretmenlerinin ve öğretmen adaylarmın müzik öğretimine ilişkin öz yeterlik ortalamalarmın orta düzeyde; tutumlarımın olumlu ve müziğe yönelik ilgi düzeylerinin yüksek olduğu belirlenmiştir. Öğretmenlerin müzik öğretimine ilişkin tutum ve müziğe yönelik ilgi puan ortalamaları cinsiyetlerine göre farkllaş̧ıken; müzik öğretimine ilişkin öz yeterlik puanlar arasinda anlamlı bir fark bulunmamıştır. Öğretmenlerin müzik öğretimine ilişkin öz yeterlik ve tutum puan ortalamaları istatistiksel olarak mezuniyet durumlarına göre farkllaşmazken; kıdemlerine göre farkllaşmakta, müziğe yönelik ilgi puan ortalamaları ise kıdemlerine göre farkllaşmazken; mezuniyet durumlarna göre farklılaşmaktadır. Öğretmen adaylarının ise müzik öğretimine ilişkin öz yeterlik, tutum ve ilgi puan ortalamaları arasinda cinsiyetlerine, sinf düzeylerine ve mezun olduklar lise türüne göre anlaml düzeyde bir farklllaşma görülmemiştir. Her iki grupta da müzik öğretimine ilişkin öz yeterlik, tutum ve ilgi puan ortalamalarnda müzik aleti çalan grubun lehine anlamlı bir farkllaşma olduğu belirlenmiştir. Ayrıca müzik öğretimine iliş̧kin öz yeterlik ve tutum; tutum ve ilgi arasinda orta düzeyde, öz yeterlik ve ilgi arasinda ise düşük düzeyde, pozitif ve anlamlı bir ilişki olduğu sonucuna ulaşılmıştır.
\end{abstract}

Anahtar Kelimeler: Müzik öğretimi, müzik öğretimi öz yeterliği, müziğg yönelik ilgi, müzik öğretimine ilişkin tutum, sinıf öğretmenliği.

\footnotetext{
${ }^{1}$ Bu araştırma 25-27 Mart 2021 tarihinde düzenlenen 8. Uluslararası Eğitim Programları ve Öğretim Kongresi'nde sözlü bildiri olarak sunulmuştur.
} 


\title{
An Analysis of Affective Factors of In-Service and Preservice Primary School Teachers About Music Education of The Article
}

$*$

\begin{abstract}
The aim of the study is to investigate relationship between in-service and preservice primary school teachers' attitude, interest and self-efficacy related to music education based on various variables. The study group consists primary school teachers who serve in the primary schools in Adana and Gaziantep during 2019-2020 academic year and preservice teachers from the Department of Primary School Education in the same cities. Data collection tools include "Music Education Self-Efficacy Scale", "Interest in Music Scale" and "Attitude towards Teaching Music". Data were analyzed via descriptive statistics, independents samples t-test, one way ANOVA and correlation analyses. The significance level was $p<.05$. The results showed that mean scores of self-efficacy, interest and attitude scales of in-service and preservice primary school teachers were high. Students interest and attitude scores changed based on their gender, while there was no significant difference in their self-efficacy scores based on gender. Self-efficacy and attitude scores of teachers showed no significant difference based on their educational background, whereas they differed based on their length of service. In addition, interest in music scores did not differ based on length on service, while it differed based on educational background. Preservice teachers, on the other hand, had no significant difference in their self-efficacy, interest and attitude mean scores based on gender, grade level, and the type of high schools they attended. There was a significant difference in favor of the people who played a musical instrument in both groups. Furthermore, there was a positive, significant, and moderate level correlation between self-efficacy and attitude, interest and attitude, and a positive low-level correlation between self-efficacy and interest.
\end{abstract}

Key Words: Music education, music education self-efficacy, interest in music, attitude towards music education, primary school education. 


\section{Giriş}

Tüm yaşamı boyunca "Nasıl yaşamalıyım?" sorusuna cevap arayan insan, kendine davranış şeklini, beynini kullanma yöntemini, duyguların yönetiş biçimini ve benzeri tüm tercihlerini doğumundan ölümüne kadar olan yaşamı boyunca elde ettiği öğrenmeler doğrultusunda şekillendirir (Senemoğlu, 2009, s.xxi). Kendi benliğini, kişiliğini ve duygusal olgunluğunu da geliştiren ve pekiştiren insan, ruhsal olarak beslenebileceği ve tazelenebileceği bir kaynağa ihtiyaç duyar. Bu kaynağın adı müziktir. Müzik, bireylerin duygu durumlarını bedensel olarak ifade etme biçimidir. Düşünceden havada yayılan ses dalgalarına dönüşen müzikal ifadeler kelimelerle anlatılamayacak kadar yoğunlukta ve özgünlüktedir.

Bilişsel, duyuşsal ve devinişsel yönlerin beslenmesine yol açan müzik, bireyin duygularını kontrol altında tutarak duyguları ve zihni arasında mantıklı bir iletişim kurmasına, müzikal bir performans süresince kas ve duygu yapısının birlikte hareket etmesine yardım eder (Türkmen, 2016, s. 6). Müzik bir eğitim aracı olarak düşünülürse iletişim kurmakta da kullanıldığı anlaşılabilir. Çünkü insan müzik yoluyla davranışlarını değiştirebilir veya geliştirebilir. Hatta müziğe özgü bilgileri ve etkileri paylaşma yoluyla gerçekleştirebilir (Günay ve Özdemir, 2012, s.50).

Müziğe yönelik bu etkileşim müzik öğretimi ile daha planlı bir düzeyde gerçekleşir. Müzik öğretimi belli amaçlar doğrultusunda planlı ve programlı bir çalışma disipliniyle gerçekleştirilen ve sürecin sonunda bireyin kendini müzikal olarak ifade etmesini kolaylaştıran bir yolculuktur. Müzik öğretimi okul öncesi dönemde başlar ve ilkokulda da devam eder. Temel müzik bilgilerinin kazandırılmasında sınıf öğretmenlerine önemli görevler düşmektedir. Sınıf öğretmenliği programında, üçüncü yarıyılda "müzik", dördüncü yarıyılda "müzik öğretimi" adında iki ders yer alırken; 2018-2019 yılında güncellenen sınıf öğretmenliği programında "müzik öğretimi" dersi yedinci dönemde yer almaktadır. Yükseköğretim Kurulu'nun (2021, s.34) 2019 yılında yayınladığı sınıf öğretmenliği lisans programına göre müzik öğretimi dersi; ilköğretim müzik programı ile ilgili etkinlik uygulamalarını içeren bir derstir. Bu derste müzik öğretim yöntem ve teknikleri, nota, ritim ve melodiden yararlanarak şarkılar düzenlenir. Bu düzenlemenin etkili 
olabilmesi için Orff çalgıları aktif bir şekilde sürece dahil edilir. Buna ek olarak müziğin oyun, dans, drama ve konuşma ilişkisi de göz önünde bulundurulur. Ayrıca müziksel beğeninin geliştirilmesi için müzikestetik ilişkisine ve müzik dersi etkinliklerinin diğer disiplinlerle ilişkilendirilmesine dikkat edilir.

Müzik öğretimi süresince gerçekleştirilen müziksel etkinlikler, etkinliklerde seslendirilen şarkılar, bu şarkıların öğretiminde kullanılan yöntemler ve etkinlikler süresince sürece dahil edilen oyunların seçimi çok önemlidir. Öğretimi planlayan, ortamı düzenleyen ve gerekli araçgereci sağlayan öğretmenin süreçle ilgili tutumu ve hazırlı̆̆ tam olmalıdır (Kılıç, 2012, s.3). Öğretmenin bu tür bir hazırlık yapabilmesi için bazı duyuşsal özelliklerinin gelişmiş olması gerekir. Bu özelliklerin başında müzik öğretimine ilişkin öz yeterlik ve tutum gelmektedir. Müziğe yönelik ilgi de bu dersin öğretimini etkileyebilecek önemli bir duyuşsal değişkendir. Bu anlamda öğretmenin müziğe yönelik ilgisi, müzik öğretimine ilişkin öz yeterliği ve tutumu, müzik derslerinin etkililiğini arttıracak unsurlar arasında sayılabilir.

Örgütsel davranışın incelenmesinde üzerinde durulan temel konulardan birisi olan tutum (Üstüner, 2006, s.111) bireyin olaylara karş1 sergilediği tavrı, nesne ve duruma göre davranışlarını etkiler (Çalhan, 2020, s.17). Doğrudan doğruya gözlenemeyen ancak bireyin davranışlarına bakıldığında anlaşılabilen tutum doğuştan gelmez, öğrenmeye dayalı olarak oluşur ve değişkendir. Birey bir uyaran karşısında olumlu veya olumsuz tepki gösterme eğilimindeyse uyarana karşı bir tutum geliştirmiştir (Öztopalan, 2007, s.19). Öz yeterlik kişinin gerekli davranışları sergileme kapasitesiyle ilgili algısıdır ancak sonuç beklentileri davranışın beklenen sonuçlarını kapsar. Bireyler performanslarından, gözlemledikleri modellerden, sosyal ikna yöntemlerinden ve psikolojik kaynaklardan yapacakları davranışla ilişkili öz yeterlikleriyle ilgili bilgi edinirler (Schunk, 2009, s.105-106). Bu doğrultuda tutum olayların kendi doğası içindeki oluşumu ve gelişimi doğrultusunda alınan kararlar bütünü, öz yeterlik ise aslında etrafımızda yaşanan tüm olayların ve duygu durumlarının kendi üzerimizdeki yansımasıdır denilebilir. Bunlara ek olarak ilgi ise kendi içinde estetik bir objeye / olguya duyulan hayranlık veya merak duygusu barındırır. İnsan ilgi duyduğu ve kendisiyle arasında duygusal bir etkileşim olduğunu 
düşündüğü her şey için özel bir zaman ayırmak ister. Müzik eğitimi alan bireylerin müziği tercih etmelerindeki ana sebep müziğe olan ilgileri doğrultusunda kendilerini geliştirmek, geliştirdikleri süre içerisinde artan öz yeterlikleri doğrultusunda da müziğe karşı olan tutumlarını ya da müzikal ifade becerilerini hayatlarının önemli bir yerine oturtarak dış dünyayı algılama ve yorumlama becerilerine müzikal açıdan bir destek sağlamaktır.

Müzik bireylerde kültürel benliğin erken yaşlardan itibaren oluşmasına zemin hazırlar (Çelik, 2018, s.8). Çocukluktan itibaren müzik eğitimi alan bireyler kendi gelişimlerinde zihinsel ve kültürel bir avantaj elde ederler. Müziğin insan yaşamında ne kadar etkili olduğunu Feridunoğlu (2004, s.1) “Kültür düzeyi ayırt edilmeksizin tüm insanlık tarafından algılanan ve duygusal olarak bir karşılık bulan müzik insan yaşamında önemli bir yere sahiptir" sözleriyle açıklamaktadır. Bireyin bilişsel, duyuşsal ve devinişsel yönlerden bir bütün olarak yetişmesini önemseyen çağdaş eğitimde müzik eğitimi alan her birey duygu ve düşüncesini özgürce ifade edebilme, kendi sınırlarını tanıyıp bu sınırları genişletebilme yeteneğine kavuşur (Yağışan, Sünbül, ve Yücalan, 2007, s.248). İçinde bulunduğu koşul ve ortamda müzikal olarak düşüncesini özgürce ifade edebilmek hatta bu özgürlük doğrultusunda müziği kendince yorumlayıp bedeninde geliştirdiği jest ve mimiklerle yansıtabilmek çağdaş eğitimin gerekliliğidir. Türkmen (2016, s.4) özellikle ilköğretim çağındaki çocukların tüm dünyada ortak dil olarak kabul edilen müzik aracığıyla farklı derslerde öğrendiklerini pekiştirme fırsatı bulduklarını ifade etmektedir. Bu sebeple kariyerlerine sinıf öğretmeni olarak devam edecek olan öğretmen adaylarının müzikal donanımlarını tamamlaması ve öğrendiklerini sınıf ortamında uygulamalı olarak hayata geçirmesi çok önemlidir (Çevik, 2011). Müzikal olarak kendini doğru ifade edemeyen bir sınıf öğretmeni aynı ortamda bulunan öğrencilerinin alana özgü becerileri kazanmalarında yeteri kadar etkili olamayabilir.

Müzik öğretimi alanında yapılan çalışmalar incelendiğinde, müzik okuryazarlığı, ilgi, tutum ve öz yeterliğe yönelik ölçek geliştirme çalışmalarının (Okay, Gençel Ataman ve Kırtak Ad, 2015), (Şeker ve Sayg1, 2013), (Afacan, 2008), (Afacan ve Şentürk, 2016) yapıldı̆̆ görülmektedir. Buna ek olarak sınıf öğretmeni adaylarının müzik 
öğretimi öz yeterlik düzeyleri (Çevik, 2011), müzik öğretimine ilişkin tutumları ve müzik öğretimi öz yeterlik inançları (Çelik ve Yetim , 2017) ve sınıf öğretmeni adaylarının eğitim gördükleri süre boyunca müzik öğretimi dersine yönelik görüşleri de (Kurtuldu, 2009) çalışmalara konu edilmiş, ayrıca sınıf öğretmenlerinin müzik dersine yönelik bilgi ve birikimleriyle gerek ders içinde gerekse dışında gerçekleştirdiği müziksel etkinliklerin belirlenmesi ve bu alandaki eksikliklerin belirlenip iyileştirici çözümler sunulunması amacıyla çalışmalar gerçekleştirilmiştir (Karan, 2008). Bu çalışmada daha öncekilerden farklı olarak, müzik öğretimine ilişkin öz yeterlik, tutum ve müziğe yönelik ilgi bir arada ele alınmış ve örneklem grubuna sınıf öğretmenliği mesleğini aktif olarak yapan veya bu mesleği yapmak üzere öğrenim gören iki grup dahil edilmiştir.

Sınıf öğretmenlerinin ve sınıf öğretmeni adaylarının müzik öğretimine ilişkin duyuşsal özelliklerinin cinsiyet, öğrenim gördükleri üniversite ve sinıf düzeyi, mezun olunan lise veya yüksek öğretim türü, mesleki kıdemi, müzik aleti çalma deneyimi gibi değişkenlere göre incelenmesiyle, öğretmen yetiştirme ve hizmet içi eğitim süreçlerinde bazı yaklaşımların ve standartların oluşturulması açısından bu araştırmanın önemli olduğu düşünülmektedir. Müzik öğretimi sürecinin daha etkili hale getirilebilmesi adına bu duyuşsal özelliklerin ortaya çıkarılması ile mevcut durumun resmedilmesi ve alınabilecek önlemler için bir gerekçe oluşturması beklenmektedir.

\section{Araştırmanın Amacı}

$\mathrm{Bu}$ araştırma, sınıf öğretmeni adayları ve sınıf öğretmenlerinin müzik öğretimine ilişkin öz yeterlik, tutum ve müziğe yönelik ilgi düzeylerini çeşitli değişkenlere göre incelemek ve bunlar arasında bir ilişki olup olmadığını, varsa bu ilişkinin ne yönde ve hangi düzeyde olduğunu belirlemek amacıyla yapılmıştır.

$\mathrm{Bu}$ genel amaç doğrultusunda araştırmanın alt amaçları:

1. Sınıf öğretmenlerinin ve öğretmen adaylarının müzik öğretimine ilişkin öz yeterlik, tutum ve müziğe yönelik ilgi düzeyleri nasıldır?

Sınıf öğretmenlerinin müzik öğretimine ilişkin öz yeterlik, tutum ve müziğe yönelik ilgi düzeyleri, 
2. Cinsiyetlerine,

3. En son mezun oldukları yüksek öğretim kurumuna,

4. Mesleki kıdemlerine,

5. Müzik aleti çalma deneyimlerine göre anlamlı düzeyde farklılaşmakta mıdır?

Sınıf öğretmeni adaylarının müzik öğretimine ilişkin öz yeterlik, tutum ve müziğe yönelik ilgi düzeyleri,

6. Cinsiyetlerine,

7. Sinıf düzeylerine,

8. Mezun oldukları lise türüne ve

9. Müzik aleti çalma deneyimlerine göre anlamlı düzeyde farklılaşmakta mıdır?

10. Müzik öğretimine ilişkin öz yeterlik, tutum ve müziğe yönelik ilgi arasında anlamlı bir ilişki var mıdır? şeklinde sıralanabilir.

\section{Yöntem}

\section{Araștırmanın Modeli}

Araştırma, betimsel tarama modelinde tasarlanmıştır. Betimsel araştırmalar, verilen bir durumu olabildiğince tam ve dikkatli bir şekilde tanımlar ve eğitim alanında en yaygın betimsel yöntem tarama çalışması kullanılır. Çünkü araştırmacılar bireylerin, grupların ya da fiziki ortamların özelliklerini özetler (Büyüköztürk, Kılıç Çakmak, Akgün, Karadeniz ve Demirel, 2019, s.21). Ayrıca bu araştırmada müzik öğretimine ilişkin öz yeterlik, tutum ve müziğe yönelik ilgi arasındaki ilişki incelendiğinden çalışma bu yönüyle ilişkisel tarama modelindedir. İlişkisel tarama modeli, iki ve daha çok sayıdaki değişken arasında birlikte değişim varlığını veya derecesini belirlemeyi amaçlayan araştırma modelidir (Karasar, 2004, s.81).

\section{Çalışma Grubu}

Araştırmanın çalışma grubu, 2019-2020 öğretim yılında Gaziantep ve Adana İl Milli Eğitim Müdürlüğüne bağlı merkez ilçelerinde bulunan ilkokullarda görev yapan 380 sinıf öğretmeninden ve bu illerde yer alan 
eğitim fakültelerinin sınıf öğretmenliği ana bilim dalında 3 . ve 4 . sinıflarda öğrenim gören 141 öğretmen adayından oluşturmaktadır. Çalışma grubuna ilişkin betimsel değerler Tablo 1'de verilmiştir.

Tablo 1. Çalışma grubuna ilişkin betimsel değerler

\begin{tabular}{|c|c|c|c|c|c|c|c|}
\hline \multicolumn{2}{|c|}{ ÖĞRETMEN } & \multirow{2}{*}{$\begin{array}{ll}\mathbf{f} \\
254\end{array}$} & \multirow{2}{*}{$\begin{array}{ll}\% \\
66.8 \\
\end{array}$} & \multicolumn{2}{|c|}{ ÖĞRETMEN ADAYI } & \multirow{2}{*}{$\begin{array}{l}\mathbf{f} \\
110\end{array}$} & \multirow{2}{*}{$\frac{\%}{78.0}$} \\
\hline Cinsiyet & Kadın & & & Cinsiyet & Kadın & & \\
\hline & Erkek & 126 & 33.2 & & Erkek & 31 & 22.0 \\
\hline \multirow[t]{5}{*}{ Kidem } & $1-5$ yıl & 65 & 17.1 & \multirow{2}{*}{$\begin{array}{l}\text { Sinıf } \\
\text { düzeyi }\end{array}$} & 3. sinif & 49 & 34.8 \\
\hline & 6-10 yil & 60 & 15.8 & & 4.sinif & 92 & 65.2 \\
\hline & 11-15 y1l & 84 & 22.1 & \multirow{6}{*}{$\begin{array}{l}\text { Mezun } \\
\text { olunan lise } \\
\text { türü }\end{array}$} & $\begin{array}{l}\text { Sosyal Bilimler } \\
\text { Lisesi }\end{array}$ & 6 & 4.3 \\
\hline & $16-20 \mathrm{yil}$ & 61 & 16.1 & & Anadolu Lisesi & 106 & 75.2 \\
\hline & $\begin{array}{l}21 \text { yil ve } \\
\text { üzeri }\end{array}$ & 110 & 28.9 & & $\begin{array}{l}\text { Meslek ve Teknik } \\
\text { Anadolu Lisesi }\end{array}$ & 3 & 2.1 \\
\hline \multirow{3}{*}{$\begin{array}{l}\text { Mezun } \\
\text { olunan } \\
\text { okul türü }\end{array}$} & $\begin{array}{l}\text { Eğitim } \\
\text { fakültesi }\end{array}$ & 331 & 87.1 & & İmam Hatip Lisesi & 9 & 6.4 \\
\hline & Ön lisans & 22 & 5.8 & & Diğer & 17 & 12.1 \\
\hline & Diğer & 27 & 7.1 & & & & \\
\hline \multirow{2}{*}{$\begin{array}{l}\text { Müzik } \\
\text { aleti çalma } \\
\text { durumu }\end{array}$} & Evet & 87 & 22.9 & \multirow{2}{*}{$\begin{array}{l}\text { Müzik } \\
\text { aleti çalma } \\
\text { durumu }\end{array}$} & Evet & 44 & 31.2 \\
\hline & Hayır & 293 & 77.1 & & Hayır & 97 & 68.8 \\
\hline Toplam & & 380 & 100 & Toplam & & 141 & 100 \\
\hline
\end{tabular}

Tablo 1'de görüldüğü gibi, bu öğretmenlerin 254'ü $(\% 66,8)$ kadın, 126 's1 $(\% 33,2)$ erkektir. Öğretmenlerin mesleki kıdemleri incelendiğinde ise 65 (\%17,1) öğretmen 1-5 yıl arası kıdeme sahipken; 60'ı $(\% 15,8)$ 6-10 yıl; 84'ü (\%22,1) 11-15 yıl; 61'i (\%16,1) 16-20 yıl; 110'u (\%28,9) 21 yıl ve üzeri kıdeme sahiptir. Öğretmenlerin 331'i $(\% 87,1)$ eğitim fakültesi, 22'si $(\% 5,8)$ ön lisans, 27 'si $(\% 3,5)$ diğer (ziraat fakültesi, lisans üstü vb.) mezunudur. Öğretmenlerin büyük çoğunluğu $(\% 77,1)$ müzik aleti çalmazken, \%22,9'u müzik aleti çalmaktadır. Öğretmen adaylarının ise 110 'u (\%78,0) kadın, 31'i (\%22,0) erkek; 49'u (\%34,8) 3. sinıf, 92'si (\%65,2) 4. sinıftır. Öğretmen adaylarının mezun oldukları lise türü incelendiğinde ise 6'sının $(\% 4,2)$ Sosyal Bilimler Lisesi, 106'sının $(\% 75,2)$ Anadolu Lisesi, üçünün $(\% 2,1)$ Mesleki ve Teknik Anadolu Lisesi, dokuzunun $(\% 6,4)$ İmam Hatip Lisesi, 17 'sinin $(\% 12,1)$ diğer mezunu olduğu görülmektedir. Öğretmen adaylarının yarısından fazlası (\%68,8) müzik aleti çalmazken, \%31,2'si müzik aleti çalmaktadır. 


\section{Veri toplama araçları}

Araştırmada veri toplama araçları olarak, “Müzik Öğretimi Öz Yeterlik Ölçeği" (Afacan, 2008), "Müziğe Yönelik İlgi Ölçeği" (Okay, Gençel Ataman ve Kırtak Ad, 2015) ve "Müzik Öğretimine İlişkin Tutum Ölçeği" (Şeker ve Saygı, 2013) kullanılmıştır.

Müzik öğretimi öz yeterlik ölçeği: Öğretmen ve öğretmen adaylarının müzik öğretimine yönelik öz yeterlik düzeylerini belirlemede, Afacan (2008) tarafından geliştirilen “Müzik Öğretimine Yönelik Öz Yeterlik Ölçeği" kullanılmıştır. Dört faktörlü ölçeğin, alt faktörleri sırasıyla "müzikte bilgi birikimine güven duygusu"; "müzikte uygulama becerisine güven duyma"; "müzikte teorik bilgiyi yaşam becerisine dönüştürme" ve "müzikte bilgi ve beceriyi kullanmada istekli olma ve kendine güven duyma" olarak adlandırılmıştır. 11 maddesi olumlu, sekiz maddesi olumsuz olan 19 maddelik ölçeğin Cronbach Alfa güvenirlik katsayısı ise .84 olarak hesaplanmıştır. Ölçek, 5-kesinlikle katılıyorum, 1-kesinlikle katılmıyorum olmak üzere 5'li Likert tipinde derecelendirilmiştir.

Müziğe yönelik ilgi ölçeği: Müziğe yönelik ilgiyi belirlemede Okay, Gençel Ataman ve Kırtak Ad (2015) tarafından geliştirilen ölçek kullanılmıştır. Ölçek, "çalgı çalmaya yönelik olumlu tutumlar", "konsere gitmeye yönelik olumlu tutumlar", "çalg1 çalmaya ve konsere gitmeye yönelik olumsuz tutumlar", "şarkı söylemeye yönelik tutumlar" ve "müzik dinlemeye yönelik tutumlar" olmak üzere beş alt faktörden oluşmaktadır. 29 maddeden oluşan ölçeğin Cronbach's Alpha iç tutarlılık katsayısı .92 olarak tespit edilmiştir. Ölçekte, "tamamen katılıyorum", "katılıyorum", "kararsızım", "katılmıyorum" ve "kesinlikle katılmiyorum" olmak üzere 5'li Likert derecelendirme yapılmıştır.

Müzik öğretimine ilişkin tutum ölçeği: Öğretmen ve öğretmen adaylarının müzik öğretimine ilişkin tutumlarını belirlemede, Şeker ve Saygı (2013) tarafından geliştirilen ve 19 maddeden oluşan müzik öğretimine ilişkin tutum ölçeği kullanılmıştır. Üç faktörlü ölçeğin alt ölçekleri, "müzik öğretimine önem verme", "müzik dersine ilişkin 
duygu ve düşünceler" ve "müzik öğretimine ilişkin akademik çalışmalar yapmak" olarak adlandırılmıştır. 5-tamamen katılıyorum, 1-tamamen katılmıyorum olmak üzere 5'li Likert tipinde derecelendirilen ölçeğin, Cronbach Alfa güvenirlik katsayısı .90 olarak hesaplanmıştır.

\section{Verilerin Toplanması ve Analizi}

Araştırma verileri, 2019-2020 öğretim yılı bahar döneminde, Gaziantep Üniversitesi Sosyal ve Beşerî Bilimler Etik Kurul Komisyonundan alınan onayla birlikte toplanmıştır. Verilerin toplanması, müzik öğretimi öz yeterlik, müziğe yönelik ilgi ve müzik öğretimine ilişkin tutum ölçeklerinin araştırmacılar tarafından çevrim içi olarak düzenlenmiş formları aracılı̆̆ıyla gerçekleştirilmiştir. Ölçeklerle ilgili maddelerden önce, katılımcıların bu çalışmaya gönüllü olarak katıldığ1 ve istedikleri zaman yanıtlamayı bırakabilecekleri bilgisi eklenmiş ve verdikleri bilgilerin bilimsel amaçlı yayınlarda kullanılmasını kabul ettiklerine dair onayları alınmıştır. Bu onaydan sonra öğretmenlere, en son mezun oldukları yüksek öğretim kurumu, kıdem, lisansüstü eğitim alma durumları; öğretmen adaylarına, sınıf düzeyi, mezun oldukları lise türü ve her iki gruba da cinsiyet ve herhangi bir müzik aleti çalma durumları sorulmuştur.

Verilerin analizinde, SPSS 20 programı aracılı̆̆ıyla betimsel analizler, bağımsız gruplar $t$ testi, tek yönlü varyans analizi, korelasyon analizinden yararlanılmıştır. Sonuçların anlamlılık düzeyi $p<.05$ olarak belirlenmiştir.

\section{Bulgular}

Araştırma bulguları, çalışmanın alt amaçları doğrultusunda sunulmuştur.

Sınıf öğretmenlerinin ve öğretmen adaylarının müzik öğretimine ilişkin öz yeterlik, tutum ve müziğe yönelik ilgi düzeyleri: Sınıf öğretmenlerinin ve öğretmen adaylarının müzik öğretimine ilişkin öz yeterlik, tutum ve müziğe yönelik ilgi düzeylerine ilişkin betimsel sonuçları Tablo 2'de sunulmuştur. 
Tablo 2. Öğretmenlerin ve öğretmen adalarının öz yeterlik, tutum ve ilgiye yönelik puanlarına ilişkin betimsel değerler

\begin{tabular}{lllllllll}
\hline \multicolumn{3}{c}{ Öğretmen $(\mathbf{N = 3 8 0 )}$} & \multicolumn{6}{c}{ Öğretmen adayı (N=141) } \\
& En az & $\begin{array}{l}\text { En } \\
\text { çok }\end{array}$ & $\bar{X}$ & $\mathrm{~S}$ & En az & $\begin{array}{l}\text { En } \\
\text { çok }\end{array}$ & $\bar{X}$ & $\mathrm{~S}$ \\
\hline Öz yeterlik & 28 & 92 & 61.11 & 12.14 & 48 & 90 & 70.09 & 9.52 \\
\hline Tutum & 38 & 95 & 76.98 & 12.39 & 47 & 95 & 83.79 & 11.26 \\
\hline İlgi & 54 & 141 & 114.94 & 16.44 & 53 & 141 & 114.55 & 18.17 \\
\hline
\end{tabular}

Tablo 2 incelendiğinde, öğretmenlerin müzik öğretimine ilişkin öz yeterlik ortalamalarının 61.11; öğretmen adaylarının ortalamalarının 70.09 olduğu görülmektedir. Öz yeterlik ölçeğinden alınabilecek en yüksek puanın 95 olduğu göz önünde bulundurulduğunda, ortalamaların orta düzeyde olduğu söylenebilir. Müzik öğretimine ilişkin tutum ortalamalarına bakıldığında, öğretmenlerin ortalamaları 76.98; öğretmen adaylarının ortalamaları ise 83.79'dur. Tutum ölçeğinden de alınabilecek en yüksek puanın 95 olduğu düşünüldüğünde, her iki grupta da tutumların olumlu olduğu söylenebilir. Müziğe yönelik ilgi ortalamaları ise öğretmenlerde 114.94; öğretmen adaylarında 114.55'tir. İlgi ölçeğinden alınabilecek en yüksek puan 145 'tir. Bu durumda her iki grubun da müziğe yönelik ilgilerinin yüksek olduğu ifade edilebilir.

Sinıf öğretmenlerinin müzik öğretimine ilişkin öz yeterlik, tutum ve müziğe yönelik ilgi düzeylerine ilişkin bulgular: Sınıf öğretmenlerinin müzik öğretimine ilişkin öz yeterlik, tutum ve müziğe yönelik ilgi düzeylerinin cinsiyetlerine göre değişip değişmediğine ilişkin bağımsız gruplar t-testi sonuçları Tablo 3'te sunulmuştur. 
Tablo 3. Öğretmenlerin öz yeterlik, tutum ve ilgiye yönelik puanlarnın cinsiyete göre bağımsız gruplar t-testi sonuçları

\begin{tabular}{llllllll}
\hline & Cinsiyet & $\mathbf{N}$ & $\bar{X}$ & $\mathbf{S}$ & $\mathbf{s d}$ & $\mathbf{t}$ & $\mathbf{p}$ \\
\hline \multirow{2}{*}{ Öz yeterlik } & Kadın & 254 & 61.68 & 12.17 & \multirow{2}{*}{378} & \multirow{2}{*}{1.308} & .192 \\
& Erkek & 126 & 59.95 & 12.05 & & & \\
Tutum & Kadın & 254 & 78.10 & 12.27 & 378 & 2.534 & .012 \\
& Erkek & 126 & 74.71 & 12.35 & & & \\
İlgi & Kadın & 254 & 117.98 & 15.58 & 378 & \multirow{2}{*}{5.300} & .000 \\
\hline
\end{tabular}

Tablo 3'e bakıldığında, kadın öğretmenlerin müzik öğretimine ilişkin öz yeterlik, tutum ve ilgi ölçeklerine ait puan ortalamalarının $(\bar{X}=61.68$; 78.10; 117.98), erkek öğretmenlere ait puan ortalamalarından $(\bar{X}$ $=59.95 ; 74.71 ; 108.81)$ daha yüksek olduğu görülmektedir. Aradaki bu farkın istatistiksel olarak farklılaşıp farklılaşmadığını anlamak için yapılan bağımsız gruplar t-testi sonuçlarına göre, müzik öğretimine ilişkin tutum ve müziğe yönelik ilgiye göre kadın öğretmenler lehine anlamlı bir farklılaşma görülürken (ttutum=2.534; tilgi=5.300; $\mathrm{p}<.05$ ), müzik öğretimine ilişkin öz yeterlik puanları arasında anlamlı düzeyde bir fark bulunmamıştır ( $\mathrm{t}=1.308 ; \mathrm{p}>.05)$.

Mezun olunan okul türü değişkeni açısından, müzik öğretimine ilişkin öz yeterlik, tutum ve müziğe yönelik ilgi puanlarına ilişkin aritmetik ortalama, standart sapma değerleri ve tek yönlü varyans analizi sonuçları Tablo 4 'te verilmiştir.

Tablo 4'e göre; öğretmenlerin müzik öğretimine ilişkin öz yeterlik puan ortalaması ön lisans mezunlarında en yüksek; tutum ve ilgi puan ortalamalarında ise diğer grubunun ortalaması daha yüksektir. Ortalamaların farklılaşmasıyla birlikte, bu ortalamalar arasında istatistiksel olarak anlamlı fark olup olmadığını belirlemek için tek yönlü varyans analizi yapılmıştır. Sonuçlara baktığımızda, öğretmenlerin müzik öğretimine ilişkin öz yeterlik ve tutum puan ortalamaları istatistiksel olarak farklılaşmazken [Föz yeterlik $(2 ; 377)=2.788$; Ftutum (2; $377)=.645 ; \mathrm{p}>.05$ ]; müziğe yönelik ilgi puan ortalamaları "diğer" mezun grubu ile ön lisans grubu arasında, "diğer" mezun grubu lehine farklılaşmaktadır $[\mathrm{F}(2 ; 377)=3.365 ; \mathrm{p}<.05)]$. 
Tablo 4. Öğretmenlerin öz yeterlik, tutum ve ilgiye yönelik puanlarının mezun olunan okul türüne göre tek yönlü varyans analizi sonuçlarn

\begin{tabular}{|c|c|c|c|c|c|c|c|}
\hline & Gruplar & $\mathbf{N}$ & $X$ & $\mathrm{~S}$ & $\mathbf{F}$ & $\mathrm{p}$ & Scheffe-f \\
\hline \multirow{4}{*}{$\begin{array}{l}\text { Öz } \\
\text { yeterlik }\end{array}$} & $\begin{array}{l}\text { Eğitim } \\
\text { fakültesi }\end{array}$ & 331 & 61.22 & 11.59 & \multirow{4}{*}{2.788} & \multirow{4}{*}{.063} & \multirow{4}{*}{--- } \\
\hline & Ön lisans & 22 & 64.77 & 14.90 & & & \\
\hline & Diğer & 27 & 56.74 & 15.26 & & & \\
\hline & Toplam & 380 & 61.11 & 12.14 & & & \\
\hline \multirow{4}{*}{ Tutum } & $\begin{array}{l}\text { Eğitim } \\
\text { fakültesi }\end{array}$ & 331 & 76.74 & 12.32 & \multirow{4}{*}{.645} & \multirow{4}{*}{.525} & \multirow{4}{*}{--- } \\
\hline & Ön lisans & 22 & 77.45 & 14.47 & & & \\
\hline & Diğer & 27 & 79.52 & 11.50 & & & \\
\hline & Toplam & 380 & 76.98 & 12.39 & & & \\
\hline \multirow{4}{*}{ İlgi } & $\begin{array}{l}\text { Eğitim } \\
\text { fakültesi }\end{array}$ & 331 & 114.82 & 16.16 & \multirow{4}{*}{3.365} & \multirow{4}{*}{.036} & \multirow{4}{*}{$\begin{array}{l}\text { Diğer>ön } \\
\text { lisans }\end{array}$} \\
\hline & Ön lisans & 22 & 109.09 & 21.11 & & & \\
\hline & Diğer & 27 & 121.15 & 14.11 & & & \\
\hline & Toplam & 380 & 114.94 & 16.44 & & & \\
\hline
\end{tabular}

Öğretmenlerin mesleki kıdemleri açısından müzik öğretimine ilişkin öz yeterlik, tutum ve müziğe yönelik ilgi puanlarına ilişkin aritmetik ortalama, standart sapma değerleri ve tek yönlü varyans analizi sonuçları Tablo 5'te verilmiştir.

Tablo 5. Öğretmenlerin öz yeterlik, tutum ve ilgiye yönelik puanlarını kıdemlerine göre tek yönlü varyans analizi sonuçları

\begin{tabular}{|c|c|c|c|c|c|c|c|}
\hline & Gruplar & $\mathbf{N}$ & $\bar{X}$ & $S$ & $\mathbf{F}$ & $\mathrm{p}$ & Scheffe-f \\
\hline \multirow{6}{*}{ Öz yeterlik } & $1-5 \mathrm{yll}$ & 65 & 66.42 & 8.18 & \multirow{6}{*}{5.276} & \multirow{6}{*}{.000} & \multirow{6}{*}{$\begin{array}{l}1-5 \text { yıl }>11-15 \\
\text { yıl } \\
1-5 \text { yıl }>21 \text { yıl } \\
\text { ve üzeri }\end{array}$} \\
\hline & 6-10 yıl & 60 & 63.10 & 9.96 & & & \\
\hline & 11-15 yil & 84 & 58.94 & 13.44 & & & \\
\hline & $16-20$ yıl & 61 & 60.16 & 12.13 & & & \\
\hline & 21 yıl ve üzeri & 110 & 59.06 & 13.19 & & & \\
\hline & Toplam & 380 & 61.11 & 12.14 & & & \\
\hline \multirow{6}{*}{ Tutum } & $1-5$ yil & 65 & 82.72 & 11.34 & \multirow{6}{*}{4.681} & \multirow{6}{*}{.001} & \multirow{6}{*}{$\begin{array}{l}1-5 \text { yıl }>11-15 \\
\text { yıl } \\
1-5 \text { yıl }>16-20 \\
\text { yıl } \\
1-5 \text { yıl }>21 \text { yıl } \\
\text { ve üzeri }\end{array}$} \\
\hline & 6-10 yil & 60 & 76.05 & 10.92 & & & \\
\hline & 11-15 yil & 84 & 74.80 & 13.84 & & & \\
\hline & $16-20$ yıl & 61 & 75.38 & 13.65 & & & \\
\hline & 21 yıl ve üzeri & 110 & 76.64 & 10.94 & & & \\
\hline & Toplam & 380 & 76.98 & 12.39 & & & \\
\hline \multirow{6}{*}{ İlgi } & $1-5$ yıl & 65 & 117.80 & 12.23 & \multirow{6}{*}{1.629} & \multirow{6}{*}{.166} & \multirow{6}{*}{--- } \\
\hline & $6-10$ y1l & 60 & 117.38 & 14.51 & & & \\
\hline & $11-15$ yil & 84 & 115.40 & 17.54 & & & \\
\hline & $16-20$ yıl & 61 & 113.41 & 16.48 & & & \\
\hline & 21 yıl ve üzeri & 110 & 112.42 & 18.40 & & & \\
\hline & Toplam & 380 & 114.94 & 16.44 & & & \\
\hline
\end{tabular}


Tablo 5'e göre; 1-5 yıl kıdeme sahip öğretmenlerin müzik öğretimine ilişkin öz yeterlik, tutum ve müziğe ilişkin ilgi puan ortalamalarının diğer gruplardan daha yüksek olduğu dikkat çekmektedir. Bir diğer dikkat çekici durum ise öz yeterlik ve ilgide ortalamaların kıdem arttıkça düşmesidir. Ortalamalar arasındaki bu farklılaşmanın istatistiksel olarak anlamlı olup olmadığını belirlemek için yapılan tek yönlü varyans analizi sonuçları incelendiğinde, müzik öğretimine ilişkin öz yeterlik ve tutum puan ortalamaları açısından anlamlı bir farklılaşma olduğu belirlenmiş [Föz yeterlik $(4 ; 375)=5.276$; Ftutum $(4 ; 375)=4.681 ; \mathrm{p}<.05$ ]; müziğe yönelik ilgiye göre puan ortalamaları açısından anlamlı bir farklılaşma görülmemiştir [Filgi $(4 ; 375)=1.629 ;$ p>.05]. Scheffe-f testi sonucuna göre farklılaşma, müzik öğretimine ilişkin öz yeterlik açısından, 1-5 yıl ile 11-15 yıl ve 21 yıl üzeri kıdeme sahip grup arasında, müzik öğretimine ilişkin tutuma göre, 1-5 yıl ile 11-15 yıl, 16-20 ve 21 yıl üzeri kıdeme sahip grup arasında 1-5 yıl kıdeme sahip grup lehinedir.

Sınıf öğretmenlerinin müzik öğretimine ilişkin öz yeterlik, tutum ve müziğe yönelik ilgi düzeylerinin müzik aleti çalma durumlarına göre değişip değişmediğine ilişkin bağımsız gruplar t-testi sonuçları Tablo 6 'da sunulmuştur.

Tablo 6. Öğretmenlerin öz yeterlik, tutum ve ilgiye yönelik puanlarının müzik aleti çalma durumlarına göre bağımsız gruplar t-testi sonuçları

\begin{tabular}{|c|c|c|c|c|c|c|c|}
\hline & Müzik aleti çalma & $\mathbf{N}$ & $\bar{X}$ & $\mathrm{~s}$ & sd & $\mathbf{t}$ & $\mathrm{p}$ \\
\hline \multirow{2}{*}{ Öz yeterlik } & Evet & 87 & 68.49 & 11.36 & \multirow[b]{2}{*}{378} & \multirow[b]{2}{*}{6.840} & \multirow[b]{2}{*}{.000} \\
\hline & Hayır & 293 & 58.91 & 11.50 & & & \\
\hline \multirow{2}{*}{ Tutum } & Evet & 87 & 82.57 & 11.08 & \multirow{2}{*}{378} & \multirow{2}{*}{4.947} & \multirow{2}{*}{.000} \\
\hline & Hayır & 293 & 75.31 & 12.28 & & & \\
\hline \multirow{2}{*}{ İlgi } & Evet & 87 & 118.25 & 17.21 & \multirow{2}{*}{378} & \multirow{2}{*}{2.149} & \multirow{2}{*}{.032} \\
\hline & Hayır & 293 & 113.96 & 16.11 & & & \\
\hline
\end{tabular}

Tablo 6 incelendiğinde, müzik aleti çalan grubun müzik öğretimine ilişkin öz yeterlik, tutum ve müziğe ilişkin ilgi puan ortalamalarının, çalmayan gruba göre daha yüksek olduğu; bu farkın istatistiksel olarak anlamlı ve müzik aleti çalan grubun lehine olduğu görülmektedir (töz

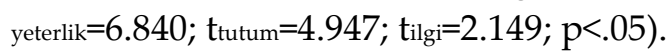

Sını öğretmenlerini adaylarının müzik öğretimine ilişkin öz yeterlik, tutum ve müziğe yönelik ilgi düzeylerine ilişkin bulgular: Sınıf 
öğretmeni adaylarının müzik öğretimine ilişkin öz yeterlik, tutum ve müziğe yönelik ilgi düzeylerinin cinsiyetlerine göre değişip, değişmediğine ilişkin bağımsız gruplar t-testi sonuçları Tablo 7'de sunulmuştur.

Tablo 7. Öğretmen adaylarnnın öz yeterlik, tutum ve ilgiye yönelik puanlarnnın cinsiyete göre bağımsız gruplar t-testi sonuçları

\begin{tabular}{|c|c|c|c|c|c|c|c|}
\hline & Cinsiyet & $\mathbf{N}$ & $X$ & S & sd & $t$ & $p$ \\
\hline \multirow{2}{*}{ Öz yeterlilik } & Kadın & 110 & 69.92 & 9.31 & \multirow{2}{*}{139} & \multirow{2}{*}{-.391} & \multirow{2}{*}{.696} \\
\hline & Erkek & 31 & 70.68 & 10.38 & & & \\
\hline \multirow{2}{*}{ Tutum } & Kadın & 110 & 83.98 & 10.73 & \multirow{2}{*}{139} & \multirow{2}{*}{.385} & \multirow{2}{*}{.701} \\
\hline & Erkek & 31 & 83.10 & 13.14 & & & \\
\hline \multirow{2}{*}{ İlgi } & Kadın & 110 & 114.68 & 18.79 & \multirow{2}{*}{139} & \multirow{2}{*}{.167} & \multirow{2}{*}{.868} \\
\hline & Erkek & 31 & 114.06 & 16.04 & & & \\
\hline
\end{tabular}

Tablo 7'ye bakıldığında, kadın ve erkek öğretmen adaylarının müzik öğretimine ilişkin öz yeterlik, tutum ve müziğe yönelik ilgi ortalamalarının birbirine oldukça yakın olduğu görülmektedir ( $\bar{X}$ öz

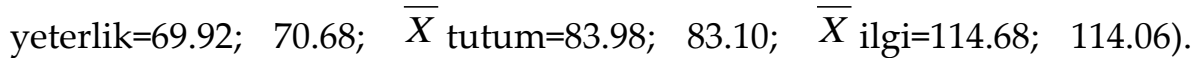
Ortalamaların istatistiksel olarak farklılaşıp farklılaşmadığını anlamak için yapılan bağımsız gruplar t-testi sonuçlarına göre, öz yeterlik, tutum ve yönelik ilgi puanları arasında cinsiyete göre anlamlı düzeyde bir fark bulunmamıştır (töz yeterlik=-.391; ttutum=.385; tilgi=.167; p $>.05)$.

Sınıf öğretmeni adaylarının müzik öğretimine ilişkin öz yeterliklerinin, tutumlarının ve müziğe yönelik ilgilerinin sınıf düzeylerine göre değişip değişmediğine ilişkin bağımsız gruplar t-testi sonuçları Tablo 8'de sunulmuştur.

Tablo 8. Öğretmen adaylarının öz yeterlik, tutum ve ilgiye yönelik puanlarnnı sinıf düzeylerine göre bağımsız gruplar t-testi sonuçları

\begin{tabular}{llllllll}
\hline & Sinıf düzeyi & $\mathbf{N}$ & $\bar{X}$ & $\mathbf{S}$ & sd & $\mathbf{t}$ & $\mathbf{p}$ \\
\hline \multirow{2}{*}{ Öz yeterlilik } & $\mathbf{3}$ & 49 & 70.00 & 10.07 & \multirow{2}{*}{139} & -.077 & .939 \\
\multirow{2}{*}{ Tutum } & $\mathbf{4}$ & 92 & 70.13 & 9.27 & & & \\
\multirow{2}{*}{ İlgi } & $\mathbf{3}$ & 49 & 85.41 & 9.70 & 139 & 1.250 & .213 \\
& $\mathbf{4}$ & 92 & 82.92 & 11.97 & & & \\
& $\mathbf{3}$ & 49 & 116.41 & 21.16 & 139 & .888 & .376 \\
\hline
\end{tabular}


Tablo 8'e bakıldığında, 3. ve 4. sinıfta öğrenim gören öğretmen adaylarının müzik öğretimine ilişkin öz yeterlik ortalamalarının birbirine yakın olduğu ( $\bar{X}$ öz yeterlik=70.00; 70.13); tutum ve müziğe yönelik ilgi ortalamalarının ise 3. sinıflarda daha yüksek olduğu görülmektedir ( $\bar{X}$

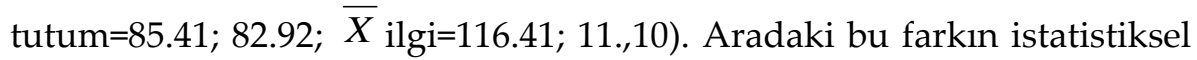
olarak farklılaşıp farklılaşmadığını anlamak için yapılan bağımsız gruplar t-testi sonuçlarına göre, öz yeterlik, tutum ve yönelik ilgi puanları arasında sınıf düzeylerine göre anlamlı bir fark bulunmamıştır

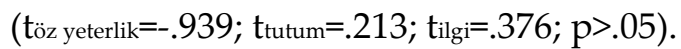

Sınıf öğretmeni adaylarının müzik öğretimine ilişkin öz yeterliklerinin, tutumlarının ve müziğe yönelik ilgilerinin mezun oldukları lise türüne göre değişip değişmediğine ilişkin bağımsız gruplar t-testi sonuçları Tablo 9'da sunulmuştur.

Tablo 9. Öğretmen adaylarıın öz yeterlik, tutum ve ilgiye yönelik puanlarını lise türüne göre bă̆ımsız gruplar t-testi sonuçları

\begin{tabular}{|c|c|c|c|c|c|c|c|}
\hline & Lise türü & $\mathrm{N}$ & $\bar{X}$ & $\mathrm{~s}$ & sd & $t$ & $\mathrm{p}$ \\
\hline \multirow{2}{*}{ Öz yeterlik } & $\begin{array}{l}\text { Anadolu } \\
\text { lisesi }\end{array}$ & 106 & 70.53 & 9.81 & \multirow[t]{2}{*}{139} & \multirow{2}{*}{.962} & \multirow{2}{*}{.338} \\
\hline & Diğer & 35 & 68.74 & 8.60 & & & \\
\hline \multirow[t]{2}{*}{ Tutum } & $\begin{array}{l}\text { Anadolu } \\
\text { lisesi }\end{array}$ & 106 & 84.50 & & \multirow[t]{2}{*}{139} & \multirow[t]{2}{*}{1.311} & \multirow[t]{2}{*}{192} \\
\hline & Diğer & 35 & 81.63 & 13.50 & & & \\
\hline \multirow[t]{2}{*}{ İlgi } & $\begin{array}{l}\text { Anadolu } \\
\text { lisesi }\end{array}$ & 106 & 116.12 & 18.11 & \multirow[t]{2}{*}{139} & \multirow[t]{2}{*}{1.808} & \multirow[t]{2}{*}{.073 } \\
\hline & Diğer & 35 & 109.77 & 17.75 & & & \\
\hline
\end{tabular}

Tablo 9'a bakıldığında, Anadolu lisesi mezunu öğretmen adaylarının müzik öğretimine ilişkin öz yeterlik, tutum ve ilgi ortalamalarının diğer gruptan daha yüksek olduğu görülmektedir ( $\bar{X}$ öz yeterlik=70.53; 68.74;

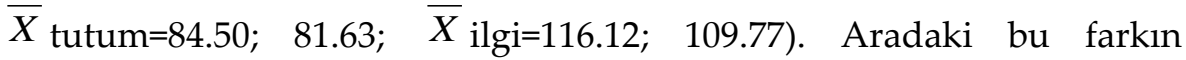
istatistiksel olarak farklılaşıp farklılaşmadığını anlamak için yapılan bağımsız gruplar t-testi sonuçlarına göre, öz yeterlik, tutum ve yönelik ilgi puanları arasında mezun olunan lise türüne göre anlamlı bir fark bulunmamıştır (töz yeterlik=-.338; tutum=.192; tilgi=.073; p>.05).

Sınıf öğretmeni adaylarının müzik öğretimine ilişkin öz yeterlik, tutum ve müziğe yönelik ilgi düzeylerinin müzik aleti çalma 
durumlarına göre değişip değişmediğine ilişkin bağımsız gruplar t-testi sonuçları Tablo 10'da sunulmuştur.

Tablo 10. Öğretmen adaylarının öz yeterlik, tutum ve ilgiye yönelik puanlarının müzik aleti çalma durumlarnna göre bağımsız gruplar t-testi sonuçları

\begin{tabular}{|c|c|c|c|c|c|c|c|}
\hline & Müzik aleti çalma & $\mathbf{N}$ & $\bar{X}$ & $S$ & sd & $t$ & $\mathrm{p}$ \\
\hline \multirow{2}{*}{ Öz yeterlilik } & Evet & 44 & 75.43 & 7.88 & \multirow{2}{*}{139} & \multirow{2}{*}{4.836} & \multirow{2}{*}{.000} \\
\hline & Hayır & 97 & 67.66 & 9.24 & & & \\
\hline \multirow{2}{*}{ Tutum } & Evet & 44 & 88.50 & 9.31 & \multirow{2}{*}{139} & \multirow{2}{*}{3.477} & \multirow{2}{*}{.001} \\
\hline & Hayır & 97 & 81.65 & 11.46 & & & \\
\hline \multirow{2}{*}{ İlgi } & Evet & 44 & 120.27 & 14.92 & \multirow{2}{*}{139} & \multirow{2}{*}{2.571} & \multirow{2}{*}{.011} \\
\hline & Hayır & 97 & 111.95 & 18.97 & & & \\
\hline
\end{tabular}

Tablo 10 incelendiğinde, müzik aleti çalan grubun müzik öğretimine ilişkin öz yeterlik, tutum ve müziğe ilişkin ilgi puan ortalamalarının, çalmayan gruba göre daha yüksek olduğu; bu farkın istatistiksel olarak anlamlı ve müzik aleti çalan grubun lehine olduğu görülmektedir (töz yeterlik=4.836; ttutum=3.477; tilgi $=2.571 ; \mathrm{p}<.05$ ).

Müzik öğretimine ilişkin öz yeterlik, tutum ve müziğe yönelik ilgi arasındaki ilişki: Araştırmada cevap aranan "Müzik öğretimine ilişkin öz yeterlik, tutum ve müziğe yönelik ilgi arasında anlamlı bir ilişki var mıdır?" sorusuna ilişkin yapılan korelasyon analizi sonuçları Tablo 11'de sunulmuştur.

Tablo 11. Değişkenler arası Pearson korelasyon katsayıları $(N=521)$

\begin{tabular}{llll}
\hline Değişkenler & Öz yeterlik & Tutum & İlgi \\
\hline Öz yeterlik & 1 & $.611^{*}$ & $.269^{*}$ \\
Tutum & $.611^{*}$ & 1 & $.512^{*}$ \\
İlgi & $.269^{*}$ & $.512^{*}$ & 1 \\
\hline
\end{tabular}

Tablo 11 incelendiğinde, müzik öğretimine ilişkin öz yeterlik ve tutum arasında orta düzeyde, pozitif ve anlamlı bir ilişki (r=.611); öz yeterlik ve ilgi arasında düşük düzeyde, pozitif ve anlamlı bir ilişki $(\mathrm{r}=.269)$; tutum ve ilgi arasında da orta düzeyde, pozitif ve anlamlı bir ilişki (r=.512) olduğu görülmektedir. 


\section{Tartışma ve Sonuç}

Araştırma sonucunda, sınıf öğretmenlerinin ve öğretmen adaylarının müzik öğretimine ilişkin öz yeterlik ortalamalarının orta düzeyde; tutumlarının olumlu ve müziğe yönelik ilgi düzeylerinin yüksek olduğu belirlenmiştir. Öz yeterliğe ilişkin bulgular Çevik (2011) ile Gülle ve Akay (2019) tarafından yapılan araştırma sonuçlarıyla da paralellik göstermektedir. Müzik öğretimine ilişkin öz yeterlik ortalamalarının orta düzeyde olması, alınan eğitimin yeterli bulunmamasına bağlanabilir. Dinç Altun ve Uzuner (2018) tarafından yapılan çalışmada, sınıf öğretmenleri üniversitede aldıkları müzik eğitiminin yeterli olmadığını ve müzik öğretimi sürecinde sınıf öğretmenlerinin birtakım sorunlar yaşadığını ifade etmişlerdir. Barış ve Özata (2009) tarafından yapılan çalışmada da sınıf öğretmenliği öğrencilerinin kendilerini, temel müzik derslerinde çok yeterli bulmadıkları; çalgı eğitiminin yetersiz olduğu, bundan dolayı da kariyerleri süresince müzik eğitimi alanındaki çocuk şarkıları dağarcığına yeterince hâkim olmadıkları belirlenmiştir.

Müzik öğretimine ilişkin öz yeterlik ortalamalarının sonuçları incelendiğinde, öğretmenlerin ortalamalarının cinsiyetlerine ve mezuniyet durumlarına göre farklılaşmadı̆̆ı, kıdemlerine göre ise farklılaştı̆̆ 1 belirlenmiştir. Alan yazın tarandığında Barry' nin (1992) araştırmasında daha önce müzik eğitimi alan öğretmenlerin müzik etkinliklerini yönetme ve yürütme becerilerinin yüksek olduğu, Austin'in (1995) çalışmasında ise sınıf öğretmeni adaylarının kendilerini müzik kabiliyeti açısından çok da yeterli görmedikleri anlaşılmaktadır. Delice (2019) tarafından yapılan çalışmada da öğretmenlerin müzik öğretimine yönelik öz yeterlik düzeylerinin cinsiyetlerine göre farklılaşmadığı görülürken; eğitim durumları ve kıdemleri açısından farklılaşma görülmüştür. Öğretmen adaylarının öz yeterlik puanlarında ise cinsiyet, sinıf düzeyi ve mezun oldukları lise türüne göre anlamlı düzeyde bir farklılaşma görülmemiştir. Araştırma sonuçları Garvis (2013), Vannatta-Hall (2010), Çelik ve Yetim (2017) tarafından yapılan çalışmanın sonuçları ile paralellik göstermektedir. Benzer şekilde, Topoğlu (2014) araştırmasında sınıf öğretmeni adaylarının müzik öğretimine yönelik öz yeterliklerinin, cinsiyetlerine göre anlamlı farklılık göstermediğini; sınıf düzeylerine göre ise anlamlı farklılık gösterdiğini 
belirlemiştir. Eren ve Ergür (2019) tarafından yapılan çalışmada ise öğretmen adaylarının müzik öğretimine yönelik öz yeterlik inançlarının sınıf düzeylerine göre anlamlı farklılık göstermezken; cinsiyete göre farklılaştığ 1 görülmüştür. Çevik (2011) tarafından yapılan çalışmada ise farklı olarak, sınıf öğretmeni adaylarının müzik öğretimi öz yeterliklerinin, cinsiyet ve sınıf düzeyine göre farklılaştığ ${ }_{1}$ belirlenmiştir. Demir Yıldız (2018) ise müzik öğretmeni adaylarının öz yeterlik düzeylerinin cinsiyetlerine göre farklılaşmadığını belirlemiştir. Özetle, ilgili alan yazında müzik öğretimine ilişkin öz yeterlik puan ortalamalarının cinsiyet ve sınıf düzeyine göre farklılaşma durumlarına ilişkin farklı sonuçların elde edildiği görülmektedir. Bu çalışmada ise öz yeterlik puanları arasında farklılık yaratan değişkenin öğretmenlerde kıdem değişkeni olduğu dikkat çekmektedir. Bu farklılık, daha az kıdeme sahip öğretmenlerin lehinedir. Bu durum, yeni mezun olan öğretmenlerin lisans eğitimlerinde aldıkları müzik öğretimine ilişkin bilgilerinin daha yeni ve daha güncel olmasına bağlanabilir.

Müzik öğretimine ilişkin tutum ortalamalarına ilişkin sonuçlar incelendiğinde, öğretmenlerin tutum ortalamalarının cinsiyetlerine ve kıdemlerine göre istatistiksel olarak farklılaştığ 1 görülürken; mezuniyet durumlarına göre farklılaşmadığı belirlenmiştir. Öğretmen adaylarının tutum puanlarında ise cinsiyet, sınıf düzeyi ve mezun oldukları lise türüne göre anlamlı düzeyde bir farklılaşma görülmemiştir. Birch'ün araştırmasında (1969) müziğe karşı tutum ile öğretmenlerin önceki müzikal geçmişleri arasında düşük bir ilişki olduğu ve erkeklerin müziğe karşı daha düşük bir tutum sergilediği görülmüştür. Evans ise (1958) araştırma sonucunda sınıf öğretmenlerinin müziğe karşı tutumlarının olumlu olduğunu, derslerde hatırı sayılır miktarda müzik öğrettiklerini, yüksek miktarda özgüven ve öğretme isteği taşıdıklarını ortaya koyan veriler elde etmiştir. Bunlara ek olarak, müziğe yönelik olumlu tutumlar geliştiren sınıf öğretmenleri ve sınıf öğretmeni adayları da mevcuttur (Hash, 2010), (Abril and Gault, 2005), (Berke and Colwell, 2004), (Giles and Frego, 2004).

Müziğe yönelik ilgi ortalamalarına ilişkin sonuçlar incelendiğinde, öğretmenlerin müziğe yönelik ilgilerinin puan ortalamalarının cinsiyetlerine ve mezuniyet durumlarına göre farklılaştığ1; kıdemlerine göre ise farklılaşmadığı gözlenmiştir. Öğretmen adaylarının ilgi 
puanlarında ise cinsiyet, sınıf düzeyi ve mezun oldukları lise türüne göre anlamlı düzeyde bir farklılaşma görülmemiştir. Baydağ'ın (2020) farklı bölümlerde öğrenim gören üniversite öğrencileriyle yaptığ çalışmasında da müziğe yönelik ilgi düzeyleri öğrencilerin yaş ve sinıf değişkenleri açısından farklılaşmazken, cinsiyet ve lise türü açısından farklılaştığ 1 görülmüştür.

Hem öğretmen hem de öğretmen adaylarının müzik öğretimine ilişkin öz yeterlik, tutum ve müziğe yönelik ilgi puan ortalamalarında müzik aleti çalan grubun lehine anlamlı bir farklılaşma olduğu belirlenmiştir. Ancak ilgili alan yazın tarandığında, bu üç duyuşsal özelliğin tümüne yönelik böyle bir farklılaşmanın ifade edildiği herhangi bir çalışmaya rastlanamamıştır. Bu durumda, bir müzik aleti çalmak, müziğe yönelik ilginin bir yansıması olarak açıklanabilir. İlgi duyulan bir alanda öğretim yapmak da kendini daha yeterli hissetmeyi ve daha pozitif bir tutumu beraberinde getirir. Bu durumu destekler nitelikte, araştırmada, müzik öğretimine ilişkin öz yeterlik ve tutum; tutum ve ilgi arasında orta düzeyde, öz yeterlik ve ilgi arasında ise düşük düzeyde, pozitif ve anlamlı bir ilişki olduğu sonucuna ulaşılmıştır. Çelik ve Yetim (2017) tarafından yapılan çalışmada da müzik öğretimine ilişkin tutum ve öz yeterlik arasında pozitif yönde orta düzeyde ve anlamlı bir ilişki bulunmuştur. Tutum, ilgi ve öz yeterlik gibi birbirini tamamlayan duyuşsal özelliklerin kendi aralarında anlamlı bir ilişki bulunması doğal kabul edilebilir. Konuya ilgi duyulması, tutumu arttırırken; tutumun olumlu olması da bireyin kendini daha yeterli hissetmesine neden olabilir.

\section{Öneriler}

Araştırma bulguları göz önünde bulundurulduğunda, müzik aleti çalan grubun müzik öğretimine ilişkin duyuşsal özelliklerinin daha olumlu olduğu görülmüştür. Bu durum göz önünde bulundurulduğunda, müzik öğretimi yapacak öğretmenlerin, eğitim süreçlerinde bir müzik aleti çalmaları konusunda yönlendirilmeleri önerilebilir. Müzik öğretimine ilişkin öz yeterlik ve tutumun mesleğin ilk yıllarında daha yüksek olduğu belirlenmiştir. Bu durumda müzik öğretimine ilişkin hizmet içi eğitimler verilerek öğretmenlerin müzik öğretimine ilişkin 
tutumlarının ve öz yeterlik düzeylerinin mesleğin ilerleyen yıllarında da olumlu düzeyde kalmasına destek olunabilir.

Daha sonra yapılacak araştırmalara yönelik öneriler ise şunlardır: $\mathrm{Bu}$ araştırmada veriler Likert tipi ölçeklerle toplanmıştır. Daha sonra yapılacak çalışmalarda, müzik öğretimine ilişkin öz yeterlik, tutum ve müziğe yönelik ilginin kaynağı hakkında daha derinlemesine bilgiler toplayabilmek için görüşme ve gözlem gibi nitel veri toplama araçlarının kullanıldığ1 araştırmalar yapılabilir. Bu çalışma, sınıf öğretmenleri ve adayları ile gerçekleştirilmiştir. Başka çalışmalarda müzik öğretimi yapan diğer branşlardaki öğretmenlerin (müzik, okul öncesi vb..) müzik öğretimine ilişkin duyuşsal özellikleri araştırılabilir. 
EXTENDED ABSTRACT

\title{
An Analysis of Affective Factors of In-Service and Preservice Primary School Teachers About Music Education of The Article
}

\author{
Hasan Açılmış- Bilge Kuşdemir Kayıran \\ Gaziantep University
}

We, as human beings, look for the answer to the question of "How should I live?" during the journey of life. From cradle to grave, we strive to learn how to use our brain, behaviors, and emotions and shape them accordingly (Senemoğlu, 2009, p.xxi). Therefore, we need a source to feed and refresh our soul, and to develop our personality and emotional maturity. This source is music.

Music helps feed cognitive, affective and psychomotor domains, establish a rational communication between emotions and mind, activates muscles and emotions simultaneously during a musical performance (Türkmen, 2016, s. 6) Music is a way of communication as well as a tool of education. Moreover, it can influence and improve people's behaviors with the help of sharing musical information and impressions (Günay and Özdemir, 2012, p.50).

Music education carries music interaction to a more planned level. Music education is a journey that is carried out with a planned and programmed study discipline in line with certain purposes and facilitates the individual's musical expression. Studies in the field of music education include scale development studies about the attitude, interest, literacy and self-efficacy in music (Okay, Gençel Ataman and Kırtak Ad, 2015),(Şeker and Sayg1, 2013),(Afacan, 2008),(Afacan and Şentürk , 2016) Additionally, there are studies that have investigated the self-efficacy levels of primary school teachers (Çevik, 2011), their attitudes towards music education (Çelik and Yetim, 2017), and their opinions about music education they have received during their undergraduate education (Kurtuldu, 2009). The present study, different than other studies, aims to examine the attitude, interest, and self- 
efficacy of in-service and preservice primary school teachers regarding music altogether.

This study contributes to the field in the sense that the results provide implications for in-service and preservice teacher education by examining the affective factors in relation to music education with demographic variables such as gender, educational background, and grade level.

The aim of the study is to investigate relationship between in-service and preservice primary school teachers' attitude, interest and selfefficacy related to music education based on various variables (gender, length of service, grade level etc.).

The present study is a descriptive study. The study aims to investigate the relationship between attitude, interest, and self-efficacy regarding music teaching, therefore the correlational research model is employed. The study group consists of 380 primary school teachers who serve in the primary schools in Adana and Gaziantep during 2019-2020 academic year and 141 3rd and 4th grade preservice teachers from the Department of Primary School Education in the same cities. Data collection tools include "Music Education Self-Efficacy Scale"(Afacan, 2008), "Interest in Music Scale"(Okay, Gençel Ataman, \& Kırtak Ad, 2015) and "Attitude towards Teaching Music" (Şeker \& Sayg1, 2013). Data was collected during the spring term of 2019-2020 academic year via online forms with aforementioned scales. Data were analyzed via descriptive statistics, independents samples t-test, one way ANOVA and correlation analyses. The significance level was $p<.05$.

The results showed that mean scores of self-efficacy, interest and attitude scales of in-service and preservice primary school teachers were high. Student's interest and attitude scores changed based on their gender, while there was no significant difference in their self-efficacy scores based on gender. Self-efficacy and attitude scores of teachers showed no significant difference based on their educational background, whereas they differed based on their length of service. In addition, interest in music scores did not differ based on length on service, while it differed based on educational background. Preservice teachers, on the other hand, had no significant difference in their self-efficacy, interest and attitude mean scores based on gender, grade level, and the type of 
high schools they attended. There was a significant difference in favor of the people who played a musical instrument in both groups. Furthermore, there was a positive, significant, and moderate level correlation between self-efficacy and attitude, interest and attitude, and a positive low-level correlation between self-efficacy and interest.

Considering the research findings, it was seen that the affective characteristics of the musical instrument group regarding music teaching were more positive. Considering this situation, it can be suggested that teachers who will teach music should be guided to play a musical instrument during their education process. It was determined that selfefficacy and attitude towards music teaching were higher in the first years of the profession. In this case, by giving in-service training on music education, it can be supported to keep teachers' attitudes and selfefficacy levels towards music education at a positive level in the later years of the profession.

Suggestions for future research are as follows: In this study, data were collected with Likert-type scales. In future studies, studies using qualitative data collection tools such as interviews and observations can be conducted to gather more in-depth information about the selfefficacy, attitude and source of interest in music teaching. This study was carried out with classroom teachers and candidates. In other studies, the affective characteristics of teachers in other branches (music, preschool, etc.) who teach music can be investigated.

\section{Kaynakça / References}

Abril, C. R. and Gault, B. M. (2005). Elementary educators' perceptions of elementary general music instructional Goals. Bulletin of the Council for Research in Music Education, 164, 61-69.

Afacan, Ş. (2008). Müzik Öğretimi Öz Yeterlilik Ölçeği. Ahi Evran Üniversitesi Kırşehir Eğitim Fakültesi Dergisi, 9, 1-11.

Afacan, Ş. ve Şentürk, N. (2016). Okul Öncesi ve Sınıf Eğitimi Anabilim Dallarına Yönelik Müzik Okuryazarlı̆̆ı Ölçeğinin geliştirilmesi. International Journal of Eurasia Social Sciences, 25, 228-247. 
Austin, J. R. (1995). Future Classroom teacher's ability self-perceptions and attributional responses to failure in music: Do music fundamentals classes make a difference? Research Perspectives in Music Education, $5(1), 6-15$.

Barış A. D. ve Özata, E. (2009). Sınıf Öğretmenliği Anabilim Dalında alınan müzik-müzik öğretimi derslerinin öğretmenlik uygulamalarındaki yansımaları. Mehmet Akif Ersoy Üniversitesi Eğitim Fakültesi Dergisi, 18, 27-42.

Barry, N. H. (1992). Music Education in the Elementary Music Methods Class. Journal of Music Teacher Education, 2(1),16-23.

Baydağ, C. (2020). Üniversitelerin farklı lisans bölümlerinde öğrenim gören öğrencilerin müziğe yönelik ilgi düzeylerinin incelenmesi. Fırat Üniversitesi Sosyal Bilimler Dergisi,30(1),145-158.

Berke, M. and Colwell, C. (2004). Integration of Music in the elementary school: The principal's perspective. Journal of Research in Music Education, 23(1), 6-20.

Birch, L. W. (1969). Factors related to differences in classroom teacher's attitudes toward music. Unpublished Doctora Thesis. University of Sothern California.

Büyüköztürk, Ş., Kılıç Çakmak, E., Akgün, Ö., Karadeniz, Ş. ve Demirel, F. (2019). Eğitimde bilimsel araştırma yöntemleri. Ankara: Pegem Yayınevi.

Çalhan, N. (2020). Taksim yapmaya yönelik tutum ölçeğinin geliştirilmesi. Yayımlanmamış Yüksek Lisan Tezi, Muğla Sıtkı Koçman Üniversitesi Eğitim Bilimleri Enstitüsü, Muğla.

Çelik, Y. (2018). Sını öğretmeni adaylarının müzik öğretimine ilişkin tutumları öz yeterlilik inançları ve müzik yeteneklerine ilişkin öz yeterlilikleri arasındaki ilişkinin incelenmesi. Yayımlanmamış Yüksek Lisans Tezi, Amasya Üniversitesi Sosyal BilimlER Enstitüsü, Amasya.

Çelik, Y.ve Yetim , H. (2017). Sınıf öğretmeni adaylarının müzik öğretimine ilişkin tutumları ile müzik öğretimi öz yeterlilik inançları arasındaki ilişkinin incelenmesi. Elektronik Eğitim Bilimleri Dergisi, 6(12),150-170.

Çevik, D. B. (2011). Sınıf öğretmeni adaylarının müzik öğretimi özyeterlik düzeylerinin incelenmesi. Ahi Evran Üniversitesi Eğitim Fakültesi Dergisi, 12(1), 145-168.

Delice, F. (2019). Müzik öğretmenlerinin müzik öğretimine yönelik öz yeterlik düzeyleri üzerine bir inceleme. Yayınlanmamış Yüksek Lisans Tezi, Atatürk Üniversitesi Eğitim Bilimleri Enstitüsü, Erzurum. 
Demir Yıldız, Z. (2018). Müzik öğretmeni adaylarının öz yeterlik inançlarının ve mesleğe yönelik tutumlarmın çeşitli değişkenlere göre incelenmesi. Yayınlanmamış Yüksek Lisans Tezi, Karadeniz Teknik Üniversitesi Eğitim Bilimleri Enstitüsü, Trabzon.

Dinç Altun, Z. ve Uzuner, F. G. (2018). Sınıf Öğretmenlerinin Müzik Öğretimine Yönelik Görüşlerinin İncelenmesi. Abant İzzet Baysal Üniversitesi Ĕ̆itim Fakültesi Dergisi, 18(3), 1416-1632.

Eren, B. ve Engür, D. (2019). Özel eğitim öğretmeni adaylarının müzik öğretimine yönelik özyeterlik inançlarının farklı değişkenler açısından incelenmesi. Elektronik Sosyal Bilimler Dergisi, 18(72), 2000-2018.

Evans, C. H. (1958). A study of factors affecting the attitude of the elementary classroom teacher toward teaching music. Northwestern University, Illinois.

Feridunoğlu, L. (2004). Müziğe giden yol genç müzisyenin el kitabı. İstanbul: İnkılap Kitabevi.

Garvis, S. (2013). Beginning Generalist Teacher Self-Efficacy for Music Compared with Maths and English. British Journal of Music Education, 30(1), 85-101.

Giles, A. M. and Frego, R. D. (2004). An Inventory of Music Activities Used by Elementary Classroom Teachers: An Exploratory Study. Applications of Research in Music Education, 22(2), 13-22.

Gülle, A. ve Akay, C. (2019). Sınıf öğretmeni adaylarının müzik öğretimi özyeterlik inançlarının müzik kavramına yönelik yazılı ve görsel metaforlarının incelenmesi. Uluslararası Sosyal Araştırmalar Dergisi, 12(62), 1043-1057.

Günay, E. ve Özdemir, M. A. (2012). Müzik öğretimi teknolojisi ve materyal geliştirme. İstanbul: Bağlam Yayıncilı.

Hash, P. M. (2010). Preservice classroom teachers' attitudes toward music in the elementary curriculum. Journal of Music Teacher Education, 19(2), 624.

Karan, M. (2008). Illköğretim okullarında görev yapan sınıf öğretmenlerinin müzik eğitimi alanindaki yeterlilikleri üzerine bir araştırma. Yayımlanmamış Yüksek Lisans Tezi, Gazi Üniverstesi Eğitim Bilimleri Enstitüsü, Ankara.

Karasar, N. (2004). Bilimsel araştırma yöntemi. Ankara: Nobel Yayın.

Kılıç, I. (2012). Okul öncesinde müzik eğitimi. Ankara: Pegem Akademi. 
Kurtuldu, M. K. (2009). Sınıf öğretmeni adaylarının müzik öğretimi dersine yönelik tutumlarının değerlendirilmesi. Ilköğretim Online, 8(2), 510519.

Okay, H. H., Gençel Ataman, Ö. ve Kırtak Ad, V. N. (2015). Müziğe Yönelik İlgi Ölçeği (MYï̈)'nin geçerlik ve güvenirlik çalışması. Akademik Bakış Dergisi, 51, 62-71.

Öztopalan, E. (2007). İköğretim düzeyindeki özel okullar ile devlet okullarının 6,7 ve 8. sinıföğrencilerinin müzik dersine ilişkin ttutumları ve akademik başarıları arasındaki ilişki. Yayımlanmamış Yüksek Lisans Tezi. Dokuz Eylül Üniversitesi Eğitim Bilimleri Enstitüsü, İzmir.

Schunk, D. H. (2009). Öğrenme teorileri eğitimsel bir bakışla. Ankara: Nobel Yayınevi.

Senemoğlu, N. (2009). Gelişim öğrenme ve öğretim. Ankara: Pegem Yayınevi.

Şeker, S. S. ve Saygı, C. (2013). Sınıf öğretmeni adaylarının müzik öğretimine ilişkin tutumlarını ölçmeye yönelik ölçek geliştirme çalışması. Turkish Studies - International Periodical For The Languages and History of Turkish or Turkic, 8, 1237-1246.

Topoğlu , O. (2014). Sınıf öğretmeni adaylarının müzik öğretimine yönelik özyeterlik inançlarının çeşitli değişkenler açısından incelenmesi. International Journal of Human Sciences, 11(2), 730-743.

Türkmen, E. F. (2016). Müzik eğitiminde öğretim yöntemleri. Ankara: Pegem Akdemi.

Üstüner, M. (2006). Öğretmenlik Mesleğine Yönelik Tutum Ölçeğinin geçerlik ve güvenirlik çalışması. Educational Administration: Theory and Practice, $45,109-127$.

Vannatta-Hall, J. E. (2010). Music education in erly childhood teacher education: The impact of a music methods course on pre-service teachers' percieved confidence and competence to teach music. Doctoral Dissertation, University of Illinois, Illinois.

Yağışan, N., Sünbül, A. M. ve Yücalan, Ö. B. (2007). Müzik bölümü öğrencilerinin benlik imgeleri ve denetim odaklarının incelenmesi. Sosyal Bilimler Enstitüsü Dergisi, 22(1), 243-262.

YükseköğretimKurulu.yok.gov.tr: https://www.yok.gov.tr/Documents/Kurumsal/egitim_ogretim_dairesi/Yeni-Ogretmen-Yetistirme-LisansProgramlari/Sinif_Ogretmen-ligi_Lisans_Programi09042019.pd adresinden alındı 12.01.2021 


\section{Kaynakça Bilgisi / Citation Information}

Açılmış, H. ve Kuşdemir Kayıran, B. (2021). Sınıf öğretmenlerinin ve sınıf öğretmeni adaylarının müzik öğretimine ilişkin duyuşsal özelliklerinin incelenmesi. OPUS- Uluslararası Toplum Araştırmaları Dergisi, 18(Eğitim Bilimleri Özel Sayısı), 4746-4773. DOI: 10.26466/opus.890948. 